II receptor. //Nature. 1991. V. 351. P. 233-236.

17. Orenes-Piñero E. [et al.]. Impact of polymorphisms in therenninangiotensin-aldosterone system on hypertrophic cardiomyopathy // J. Renin Angiotensin Aldosterone Syst 2011. Vol. 12, №4. P. 521-530.

18. Mathew C.C. Methods in Molecular Biology / Ed Walker J.M. New-York: Human Press, 1984. V. 2. P. 31-34.

19. Баевский Р.М. Оценка эффективности профилактических мероприятий на основе изменения адаптаци- онного потенциала системы кровообращения // Здравоохранение РФ. 1987. №8. С. 6.

20. Ахметов И.И., Попов Д.В., Астратенкова И.В., Дружевская А.М., Миссина С.С., Виноградова О.Л., Рогозкин В.А. Использование молекулярно-генетических методов для прогноза аэробных и анаэробных возможностей у спортсменов // Физиология человека. 2008. Т. 34. №3. C. 86-91.

\title{
ASSOCIATION OF POLYMORPHISM CMA 1/B (G1903A) WITH THE INDEX OXYGEN TRANSPORT SYSTEM OF THE BODY IN YOUNG MEN WITH DIFFERENT LEVELS OF MOTOR ACTIVITY
} (C) 2015

A.Z. Dautova, post-graduate student of the department of human physiology and zoology Bashkir State University, Ufa (Russia)

V.G. Shamratova, doctor of biological sciences, professor of the department of human physiology and zoology Bashkir State University, Ufa (Russia)

\begin{abstract}
In the study, we investigated the association of polymorphic locus CMA 1/B (G1903A) with indicators of oxygen transport system of the body. To determine the nucleotide substitutions in the gene CMA1/B, we used RFLPanalysis, PCR products were digested with the restriction enzyme BstXI. Analysis of the distribution of frequencies of alleles and genotypes CMA1/B showed statistically significant differences in the frequency of polymorphic variants of genotypes between athletes and controls. Athletes have predominant genotype A/A $(0,52)$, and $\mathrm{G} / \mathrm{G}(0,4)$, whereas in the control group, the most common genotype $\mathrm{A} / \mathrm{G}(0,58)$. Using factor analysis, we revealed differences in the structure of the association between indicators of oxygen transport system depending on the genotype of the gene CMA. It was revealed the association of polymorphic gene variants with red blood parameters, hemodynamic and respiratory systems, as well as with physical endurance and tolerance to the muscular load. The closest connection between the studied traits detected at polymorphic variants CMA A/A. At this genotype physical endurance largely depends on the state of the circulatory system and the respiratory system functional reserves. It was also shown the correlation between adaptive capabilities of cardiovascular system and efficiency of the heart functioning with the level of motor activity. The interaction complex of the features that characterize the activities of the cardiorespiratory system, system, causes the formation of the final phenotype, which obviously explains the detected frequency distribution of different genotypes in athletes.
\end{abstract}

Keywords: gene CMA 1/B; cardiovascular system; motor activity; oxygen-transporting system.

УДК 581.9

ФЛОРА ПАМЯТНИКА ПРИРОДЫ «НИКОЛЬСКАЯ СОПКА» В Г. ПЕТРОПАВЛОВСКЕ-КАМЧАТСКОМ

(C) 2015

Е.А. Девятова, аспирант кафедры биологии и химии

Камчатский государственный университет им. Витуса Беринга, Петропавловск-Камчатский (Россия)

А.А. Вьюнова, студентка психолого-педагогического факультета

Камчатский государственный университет им. Витуса Беринга,

Петропавловск-Камчатский (Россия)

Л.М. Абрамова, доктор биологических наук, профессор, заведующая лабораторией дикорастущей флоры и интродукции травянистых растений

Ботанический сад-институт УНЦ РАН, Уфа (Россия)

Аннотащия. В статье представлены результаты изучения флоры памятника природы «Никольская сопка». Никольская сопка-комплексный, природно-исторический памятник регионального значения, включающий в себя сопку Никольскую и мыс Сигнальный, общей площадью 25,5 га. Природный комплекс памятника охраняется с 1980 года. Флора сосудистых растений представлена 149 видами, относящимися к 110 родам и 42 семействам, адвентивный компонент составляет 26,17\%. Наивысшее положение в спектре ведущих семейств флоры Никольской сопки занимают семейства Asteraceae и Роасеае. Преобладающей жизненной формой являются травянистые многолетние поликарпики, гемикриптофиты. Преобладающей группой по отношению к свету являются гелиофиты (53,69\%), сциофитов $(5,36 \%)$. Теневыносливые растения составляют $40,93 \%$ флоры. По отношению к степени увлажнения преобладающей группой являются мезофиты (87,25\%). Бореальный компонент изучаемой флоры представлен 105 видами $(70,47 \%)$. Большая часть полизональных видов являются адвентивными. Из долготных групп наиболее представлена евразиатская $(19,46 \%)$, циркумполярная $(16,78 \%)$, дальневосточная $(16,11 \%)$ и евразиатскоамериканская (14,09\%). Адвентивные виды представлены в основном евразиатскими элементами. Набор ведущих семейств, преобладание мезофитных экотипов и бореального типа ареала показывают выраженный бореальный характер исследуемой флоры, что соответствует зональному положению города. В адвентивной фракции флоры все виды по времени заноса являются неофитами, по способу заноса-ксенофитами. По степени натурализации большинство являются эпекофитами и приурочены к антропогенно нарушенным местообитаниям: тропинкам, пляжу, обочинам дороги, вытоптанным площадкам около памятников и клумбам. Состояние природного комплекса парка требует мониторинга в связи с активным рекреационным использованием территории.

Ключевые слова: природная флора; памятник природы; сосудистые растения; бореальная флора; парковый лес

Никольская сопка-комплексный, природно- отделяя внутреннюю гавань Петропавловской бухты, исторический памятник регионального значения, где протянулись причалы морского и рыбного портов. включающий в себя собственно сопку Никольскую Первый официальный запрет на рубку деревьев на и мыс Сигнальный, общей площадью 25,5 га [1]. сопке был принят генералом-губернатором города В.С. Сопка Никольская и мыс Сигнальный находятся в Завойко в 1849 году [2]. С 1980 года является памятником центральной части Петропавловска-Камчатского, природы регионального значения. 
Район, материалы и методы исследований

Сопка Никольская и мыс Сигнальный занимает территорию площадью 25,5 га в центральной части города, на берегу Авачинской бухты (5301'13" с.ш., 158 38'20" в.д.) и представляет собой хребет с максимальной высотой 108 м (рис. 1).

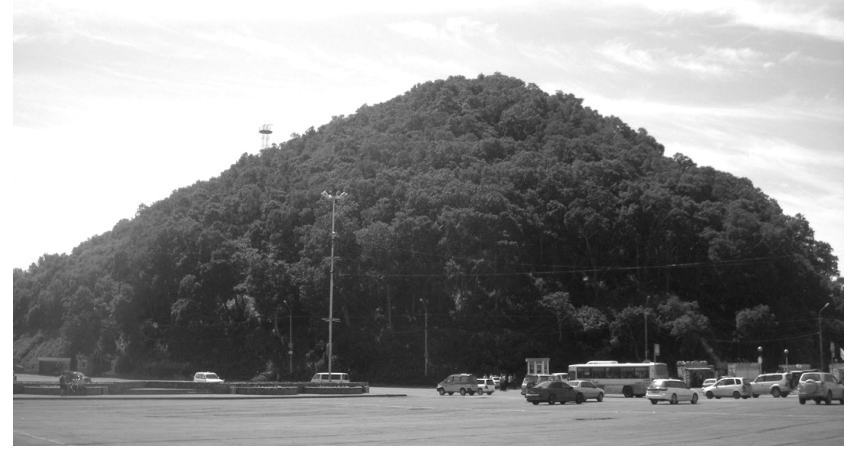

Рисунок 1 - Никольская сопка. Вид с иентральной плошади (фото Девятовой Е.А.)

Территория находится в восточной приморской подобласти и характеризуется морским климатом с избыточным увлажнением [3-5]. Средняя годовая температура воздуха $+2,1^{\circ} \mathrm{C}$. Средние суточные температуры в январе $-8,7^{\circ} \mathrm{C}$, в августе $+14^{\circ} \mathrm{C}$. Период вегетации с 22 мая по 14 октября. Среднегодовое количество осадков составляет 1300 мм, 56\% приходится на холодный период. Число дней со снежным покровом-177, средняя максимальная высота снежного покрова составляет 136 см. Западные склоны скалистые и образуют обрыв, на северных склонах и вершине расположен парковый каменноберезовый лес.

Полевой сбор материалов проводился в течение сезонов 2013-2014 гг. маршрутным методом. Использовался также гербарий КамГУ им. Витуса Беринга и КФ ТИГ ДВО РАН, и сводки В.Л. Комарова и Э. Хультена $[6,7]$. Для определения растений применялись классические ботанические методы с использованием определителей и атласов растений Камчатского края и Дальнего Востока[8-15].

Результаты и обсуждение

Флора сосудистых растений памятника «Никольская сопка» представлена 149 видами, относящимися к 110 родам и 42 семействам (табл. 1), что составляет $12,78 \%$ от флоры Камчатского края [5].

Таблица 1

Таксономический состав флоры памятника «Сопка Никольская»

\begin{tabular}{|l|c|ccc|c|c|c|}
\hline \multirow{2}{*}{ Систематическая группа } & \multicolumn{2}{|c|}{ К-во семейств } & \multicolumn{2}{l|}{ К-во родов } & \multicolumn{2}{|c|}{ К-во видов } \\
\cline { 2 - 8 } & Абс. & $\%$ & Абс. & $\%$ & Абс. & $\%$ \\
\hline Отдел Equisetophyta & 1 & 2,38 & 1 & 0,91 & 1 & 0,67 \\
\hline Отдел Polypodiophyta & 8 & 19,05 & 10 & 9,09 & 11 & 7,38 \\
\hline Отдел Pinophyta & 1 & 2,38 & 1 & 0,91 & 1 & 0,67 \\
\hline Oтдел Magnoliophyta & & & & & & \\
в том числе: & 32 & 76,19 & 98 & 89,09 & 136 & 91,28 \\
Класс Liliopsida & 7 & 16,67 & 18 & 16,36 & 31 & 20,81 \\
\hline Класс Magnoliopsida & 25 & 59,52 & 80 & 72,73 & 105 & 70,47 \\
\hline Всего & 42 & 100 & 110 & 100 & 149 & 100 \\
\hline
\end{tabular}

Большая часть видов является аборигенными, адвентивный компонент представлен 39 видами $(26,17 \%)$. Основу флоры составляют покрытосеменные растения, насчитывающие 136 видов $(91,28 \%)$, среди них двудольных-105 видов (70,47\%), однодольных-31 вид (20,81\%). Сосудистые споровые и голосеменные растения представлены 10 семействами, 12 родами и 13 видами.

Среднее видовое богатство на одно семейство составляет 3,55 вида, 12 семейств превышают этот средний уровень, в них содержится 104 вида (69,79\%). Наивысшее положение в спектре ведущих семейств флоры НиСамарский научный вестник. 2015. № 2(11)

\section{ФЛОРА ПАМЯТНИКА ПРИРОДЫ «НИКОЛЬСКАЯ СОПКА»...}

кольской сопки (табл. 2), также, как и флоры Камчатского края, занимают семейства Asteraceae и Poaceae [14]. В целом, спектр ведущих семейств соответствует и флоре региона [11], и Бореальной области [16]. Наиболее крупными родами являются Carex (6 видов), Роа (5 видов), Viola (4 вида), Draba (4 вида).

Преобладающей жизненной формой являются травянистые многолетние поликарпики (99 видов), среди них: длиннокорневищных-22 вида, клубневых-1 вид, короткокорневищных-23 вида, луковичных-5 видов, стержнекорневых-9 видов [12]. Травянистых монокарпиков (одно-, двулетних) 22 вида, из них 21 вид-стержнекорневые, 1-кистекорневой, причем 15 видов из них относятся к адвентивной фракции флоры [12]. Кустарнички представлены 3 видами, кустарники 5 видами. Деревьев 6 видов.

Таблича 2

Флористический спектр 10 ведущиих семейств

\begin{tabular}{|l|cc|c|}
\hline \multirow{2}{*}{ Семей ство } & \multicolumn{2}{|c|}{ К-во видов } & \multirow{2}{*}{ № п/п } \\
\cline { 2 - 3 } & Абс. & $\%$ & \\
\hline Asteraceae & 22 & 14,77 & 2 \\
\hline Poaceae & 15 & 10,07 & 3 \\
\hline Rosaceae & 13 & 8,72 & 4 \\
\hline Brassicaceae & 10 & 6,71 & 5 \\
\hline Ranunculaceae & 7 & 4,70 & $6-9$ \\
\hline Polygonaceae & 6 & 4,03 & $6-9$ \\
\hline Fabaceae & 6 & 4,03 & $6-9$ \\
\hline Cyperaceae & 6 & 4,03 & $6-9$ \\
\hline Caryophyllaceae & 6 & 4,03 & 10 \\
\hline Apiaceae & 5 & 3,36 & \\
\hline Bcero & 96 & 64,43 & \\
\hline
\end{tabular}

Спектр жизненных форм по К. Раункиеру представлен в таблице 3. Преобладающей формой являются гемикриптофиты-90 видов $(60,40 \%)$.

Спектр жизненных форм по К. Раункиеру

Таблица 3

\begin{tabular}{|l|cc|c|}
\hline \multirow{2}{*}{ Жизненные формы } & \multicolumn{2}{|c|}{ Компоненты флоры (кол-во видов) } & \multirow{2}{*}{ Всего во флоре } \\
\cline { 2 - 3 } & аборигенный & адвентивный & \\
\hline Фанерофиты & 11 & - & 11 \\
\hline Хамефиты & 6 & 1 & 7 \\
\hline Гемикриптофиты & 69 & 21 & 90 \\
\hline Криптофиты & 19 & 4 & 23 \\
\hline Терофиты & 5 & 13 & 18 \\
\hline
\end{tabular}

Для характеристики экологической структуры флоры были проанализированы экологические группы по отношению к требовательности к освещению и условиям увлажнения (табл. 4-5).

Таблица 4

Экологические группь по отношению к свету

\begin{tabular}{|l|c|c|c|}
\hline \multirow{2}{*}{$\begin{array}{l}\text { Экологические } \\
\text { гуппы }\end{array}$} & \multicolumn{2}{|c|}{ Компоненты флоры (кол-во видов) } & \multirow{2}{*}{ Всего во флоре } \\
\cline { 2 - 3 } & аборигенный & адвентивный & \\
\hline Сциофиты & 8 & - & 8 \\
\hline Cемигелиофиты & 54 & 7 & 61 \\
\hline Гелиофиты & 48 & 32 & 80 \\
\hline
\end{tabular}

Преобладающей группой по отношению к свету являются гелиофиты $(53,69 \%)$, при этом среди адвентивных видов гелиофиты составляют 82,05\%, а среди аборигенных-43,63\%. Доля сциофитов невелика (5,36\%). Теневыносливые растения составляют $40,93 \%$ флоры. По отношению к степени увлажнения преобладающей группой являются мезофиты (87,25\%).

Таблииа 5

Экологические группь по отношению к условиям увлажнения

\begin{tabular}{|l|c|c|c|}
\hline \multirow{2}{*}{$\begin{array}{l}\text { Экологи ческие } \\
\text { группы }\end{array}$} & \multicolumn{2}{|c|}{ Компоненты флоры (кол-во видов) } & \multirow{2}{*}{$\begin{array}{c}\text { Всего во } \\
\text { флоре }\end{array}$} \\
\cline { 2 - 3 } Гигрофиты & аборигенный & адвентивный & 6 \\
\hline Мезогигрофиты & 5 & 1 & 4 \\
\hline Гигрофильная группа: & 3 & 1 & 10 \\
\hline Гигромезофиты & 8 & 2 & 22 \\
\hline Мезофиты & 19 & 3 & 90 \\
\hline Ксеромезофиты & 66 & 24 & 18 \\
\hline Мезофильная группа: & 12 & 6 & 130 \\
\hline Мезоксерофиты & 97 & 33 & 6 \\
\hline Ксерофиты & 3 & 3 & 3 \\
\hline Ксерофильная группа: & 2 & 1 & 9 \\
\hline
\end{tabular}


Распределение видов флоры Никольской сопки по принадлежности к той или иной широтной или долготной группе представлено в таблицах 6 и 7.

Структура широтных элементов флоры Таблиия 6

\begin{tabular}{|l|cc|c|}
\hline \multirow{2}{*}{ Широтная группа } & \multicolumn{2}{|c|}{ Компонент флоры (кол-во видов) } & \multirow{2}{*}{ Всего во флоре } \\
\cline { 2 - 3 } & аборигенный & адвентивный & \\
\hline Аркто-альпийская & 5 & - & 5 \\
\hline Гипоарктическая & 14 & - & 14 \\
\hline Бореальная & 83 & 22 & 105 \\
\hline Неморальная & 5 & 3 & 8 \\
\hline Полизональная & 3 & 14 & 17 \\
\hline
\end{tabular}

Флора Камчатки характеризуется как бореальная [14]. При этом бореальный компонент изучаемой флоры составляет 105 видов $(70,47 \%)$. Большая часть полизональных видов являются адвентивными.

Из долготных групп наиболее представлена евразиатская $(19,46 \%)$, циркумполярная $(16,78 \%)$, дальневосточная $(16,11 \%)$ и евразиатско-американская $(14,09 \%)$ Адвентивные виды представлены в основном евразиатскими элементами.

Структура долготных элементов флоры

\begin{tabular}{|l|c|c|c|}
\hline \multirow{2}{*}{ Долготная группа } & \multicolumn{2}{|c|}{ Компонент флоры (кол-во видов) } & \multirow{2}{*}{ Всего во флоре } \\
\cline { 2 - 3 } & аборигенный & адвентивный & \\
\hline Европейская & 1 & 1 & 2 \\
\hline Евро-сибирская & 1 & 3 & 4 \\
\hline Сибирская & 2 & - & 2 \\
\hline Азиатская & 1 & - & 11 \\
\hline Восточно-азиатская & 11 & - & 24 \\
\hline Дальневосточная & 23 & 1 & 29 \\
\hline Евразиатская & 11 & - & 18 \\
\hline Американская & 4 & 1 & 21 \\
\hline $\begin{array}{l}\text { Азиатско- } \\
\text { американская }\end{array}$ & 17 & 7 & 25 \\
\hline $\begin{array}{l}\text { Еврази атско- } \\
\text { американская }\end{array}$ & 14 & 2 & 8 \\
\hline Циркумп олярная & 23 & 6 & \\
\hline Космополитная & 2 & &
\end{tabular}

В адвентивной фракции флоры все виды по времени заноса являются неофитами, по способу заноса-ксенофитами (табл. 8). По степени натурализации большинство являются эпекофитами и приурочены к антропогенно нарушенным местообитаниям: тропинкам, пляжу, обочинам дороги, вытоптанным площадкам около памятников и клумбам.

В начале XX века Никольская сопка, в связи с eе удобным расположением, становилась объектом изучения многих исследователей, работавших или проживавших на Камчатке: В.И. Рубинского (1908- 1909 гг.), Б.В. Перфильева (1910- 1911 гг.), Эрика Хультена (1920- 1922 гг.), П.Т. Новограбленова, а также выдающегося российского ботаника В.Л. Комарова-руководителя Ботанического отдела Камчатской экспедиции Русского географического общества (1908- 1909 гг.) [17-20].

Кроме того, Никольская сопка занимает особое место в истории города и является памятником российской воинской славы. На территории парка расположены памятники героической обороны Петропавловска-Камчатского в 1854 г.: макет батареи А.П. Максутова, памятник героям 3-й батареи А.П. Максутова, памятник Часовня на братской могиле погибших защитников Петропавловского порта, памятник Славы героям обороны Петропавловска от нападения англо-французской эскадры.

В настоящее время Никольская сопка является объектом рекреационного использования и посещается большим количеством горожан и гостей города. Однако отсутствие информационных указателей, эколого-просветительских мероприятий и мониторинга состояния природного комплекса парка вызывает серьёзные опасения за сохранность природной флоры Никольской сопки.
Особенности адвентивной фракции флоры

\begin{tabular}{|c|c|c|c|c|c|}
\hline № & Вид & Семейство & $\begin{array}{l}\text { По } \\
\text { времени } \\
\text { заноса }\end{array}$ & $\begin{array}{l}\text { По способу } \\
\text { заноса }\end{array}$ & $\begin{array}{|lr|}\text { По степени } \\
\text { натурализаци и }\end{array}$ \\
\hline 1 & Carum carvi & Apiaceae & Неофит & Ксенофит & Эпекофит \\
\hline 2 & Cirsium setosum & Asteraceae & Неофит & Ксенофит & Эпекофит \\
\hline 3 & Taraxacum officinale & Asteraceae & Неофит & Ксенофит & Эпекофит \\
\hline 4 & Leontodon autumnalis & Asteraceae & Неофит & Ксенофит & Эпекофит \\
\hline 5 & Achillaea millefolium & Asteraceae & Неофит & Ксенофит & Эпекофит \\
\hline 6 & Arctium tomentosum & Asteraceae & Неофит & Ксенофит & Эпекофит \\
\hline 7 & Lepidotheca suaveolens & Asteraceae & Неофит & Ксенофит & Эпекофит \\
\hline 8 & Leucanthemum vulgare & Asteraceae & Неофит & Ксенофит & Эпекофит \\
\hline 9 & Brassica campestris & Brassicaceae & Неофит & Ксенофит & Эргазиофит \\
\hline 10 & Capsella bursa-pastoris & Brassicaceae & Неофит & Ксенофит & Эпекофит \\
\hline 11 & Rorippa barbareifolia & Brassicaceae & Неофит & Ксенофит & Эпекофит \\
\hline 12 & Stellaria media & Caryophyllaceae & Неофит & Ксенофит & $\begin{array}{l}\text { Эпекофит, } \\
\text { эргазиофит }\end{array}$ \\
\hline 13 & Obernabehen & Caryophyllaceae & Неофит & сенофит & Эпекофит \\
\hline 14 & Cerastium holosteoides & Caryophyllaceae & Неофит & Ксенофит & Эпекофит \\
\hline 15 & Chenopodium albrom & Chenopodiaceae & Неофит & Ксенофит & Эпекофит \\
\hline 16 & Amoria repens & Fabaceae & Неофит & Ксенофит & Эпекофит \\
\hline 17 & Trifolizom hybridum & Fabaceae & Неофит & Ксенофит & Эпекофит \\
\hline 18 & Trifolium pratense & Fabaceae & Неофит & Ксенофит & Эргазиофит \\
\hline 19 & Viciacracca & Fabaceae & Неофит & Ксенофит & Эпекофит \\
\hline 20 & Galeopsis bifida & Lamiaceae & Неофит & Ксенофит & Эпекофит \\
\hline 21 & Plantago major & Plantaginaceae & Неофит & Ксенофит & Эпекофит \\
\hline 22 & Dactylis glomerata & Poaceae & Неофит & Ксенофит & Эпекофит \\
\hline 23 & Bromopsis inermis & Poaceae & Неофит & Ксенофит & Эпекофит \\
\hline 24 & Elytrigia repens & Poaceae & Неофит & Ксенофит & Эпекофит \\
\hline 25 & Phleum pratense & Poaceae & Неофит & Ксенофит & Эпекофит \\
\hline 26 & Festuca pratensis & Poaceae & Неофит & Ксенофит & Эпекофит \\
\hline 27 & Poа апnйa & Poaceae & Неофит & Ксенофит & Эпекофит \\
\hline 28 & Poa anguistifolia & Poaceae & Неофит & Ксенофит & Эпекофит \\
\hline 29 & Poa pratensis & Poaceae & Неофит & Ксенофит & Эпекофит \\
\hline 30 & Agrostis gigantea & Poaceae & Неофит & Ксенофит & Эпекофит \\
\hline 31 & Acetosella vulgaris & Polygonaceae & Неофит & Ксенофит & Эпекофит \\
\hline 32 & Rumex longifolius & Polvgonaceae & Неофит & Ксенофит & Эпекофит \\
\hline 33 & Polygonum aviculare & Polygonaceae & Неофит & Ксенофит & Эпекофит \\
\hline 34 & Fallopia convolvulus & Polygonaceae & Неофит & Ксенофит & Эпекофит \\
\hline 35 & Ranunculus acris & Ranunculaceae & Неофит & Ксенофит & Эпекофит \\
\hline 36 & Geum allepicum & Rosaceae & Неофит & Ксенофит & Эпекофит \\
\hline 37 & Potentilla norvegica & Rosaceae & Неофит & Ксенофит & $\begin{array}{l}\text { Эпекофит, } \\
\text { агриофит }\end{array}$ \\
\hline 38 & Euphrasia maximowiczii & Scrophulcriaceae & Неофит & Ксенофит & Эпекофит \\
\hline 39 & Rhinanthus minor & Scrophulariaceae & Неофит & Ксенофит & Эпекофит \\
\hline
\end{tabular}

Таким образом, значение Никольской сопки неоднозначно и требует решения двух противоположных проблем: сохранения и возможного восстановления естественного природного комплекса сопки и ее рекреационного использования как памятника истории.

\section{СПИСОК ЛИТЕРАТУРЫ}

1. Паспорт памятника природы «Сопка Никольская» / сост. Т.А. Шубина, И.Н. Каразия, 1994. Фонды министерства природных ресурсов и экологии правительства Камчатского края.

2. Витер И.В., Смышляев А.А. Город над Авачинской бухтой. История г. Петропавловска-Камчатского. Петропавловск-Камчатский. 2011. 316 с.

3. Кондратюк В.И. Климат Петропавловска-Камчатского. Л.: Гидрометеоиздат, 1983. 167 с.

4. Кондратюк В.И. Климат Камчатки. М.: Гидрометеоиздат, 1974. 204 с

5. Петропавловск-Камчатский: историко-географический атлас. Петропавловск-Камчатский: АО «Камчаткнига». 1994. 96 с.

6. Hulten E. Flora of Kamchatka and the ajacent islands // Kungl. Svenska Vetenskapsaladem. Handl. Ser. 3. Bd.5. №1. 1927. 346 p.; №2. 1928. 218 p.; Bd. 8. №1. 1929.213 p.; №2. 1930.358 p.

7. Комаров В. Л. Флора полуострова Камчатки. Л.: Изд-во АН СССР, Т. 1. 1927. 339 с.; Т. 2. 1929. 369 с.; T. 3. $1930.210 \mathrm{c}$.

8. Флора и растительность Магаданской области (конспект растений и очерк растительности).Магадан: ИБПС ДВО РАН, 2010. 364 с.

9. Нешатаева В.Ю. Растительность полуострова Камчатка / Отв. ред. проф. В.Т. Ярмишко. М.: Товарищество научных изданий КМК. 2009. 537 с.

10. Лысенко Д.С. Синантропная флора Магаданской области. Магадан: СВНЦ ДВО РАН. 2012. 111 с.

11. Сосудистые растения советского Дальнего Востока: В 8 т. / Под ред. С.С. Харкевича. Л.: Наука. 
1985- 1996. Т. 1-8.

12. Безделев А.Б., Безделева Т.А. Жизненные формы семенных растений российского Дальнего Востока. Владивосток: Дальнаука. 2006. 296 с.

13. Якубов В.В., Чернягина О.А. Каталог флоры Камчатки (сосудистые растения). Петропавловск-Камчатский, Изд-во «Камчатпресс». 2004. 165 с.

14. Определитель сосудистых растений Камчатской области / Под ред. С.С. Харкевича. М.: Наука. $1981.411 \mathrm{c}$.

15. Березуцкий М.А., Кашин А.С. Антропогенная трансформация флоры и растительности: Учебное пособие. Саратов: ИЦ «Наука», 2008. 100 с.

16. Толмачев А.И. Введение в географию растений. Изд-во Ленингр. ун-та. 1974. 244 с.

17. Якубов В.В., Чернягина О.А. Ботанические исследования В.Л. Комарова и Э. Хультена на Камчатке // Сохранение биоразнообразия Камчатки и прилега- ющих морей: Материалы X международной научной конференции, посвященной 300-летию со дня рождения г.В. Стеллера. Петропавловск-Камчатский: Камчатпресс. 2009. С. 200-204.

18. Девятова Е.А. Обзор ботанический исследований Петропавловска-Камчатского // Природная среда Камчатки // Материалы XII Региональной молодежной научной конференции «Природная среда Камчатки». 16 апреля 2013 г. Петропавловск-Камчатский: Институт вулканологии и сейсмологии ДВО РАН. 2013. С. $149-162$.

19. Комаров В.Л. Ботанический очерк Камчатки // Камчатский сборник. Т. 1. Л.: Изд-во АН СССР. 1940. C. 5-52.

20. Комаров В.Л. Путешествие по Камчатке в 19081909 гг. // Камчатская экспедиция Ф.П. Рябушинского. Ботан. отд. СПб. 1912. Вып. 1. 456 с.

\section{FLORA OF THE NATURAL MONUMENT "NICOLSKAYA SOPKA" IN PETROPAVLOVVSK-KAMCHATSKY}

(C) 2015

E.A. Devyatova, post-graduate student of department of biology and chemistry

Vitus Bering Kamchatka State University, Petropavlovsk-Kamchatsky (Russia)

A.A. Vyunova, student of faculty of psychology and pedagogics

Vitus Bering Kamchatka State University, Petropavlovsk-Kamchatsky (Russia)

L.M. Abramova, doctor of biological sciences, professor, head of the laboratory of wild flora and introduction of herbaceous plants

Botanical Garden-Institute Ufa Scientific Centre Russian Academy of Sciences, Ufa (Russia)

Abstract. This paper reports the results of studying flora of the natural monument "Nicolskaya sopka". The vascular flora is represented by 149 species belonging to 110 genus and 42 families, adventive component is $26.17 \%$. "Nicolskaya sopka" is the complex, natural and historical monument of regional value including the Nikolskaya hill and the Signalnyi cape with a total area of 25,5 hectares. The natural complex of a monument is protected since 1980 . The flora of vascular plants is presented by 149 species relating to 110 genus and 42 families, the adventive component makes $26,17 \%$. The highest position in a range of the leading families of flora of the Nikolskay hill is held by Asteraceae and Poaceae. The prevailing vital form is herbaceous perennial polycarpic, hemicryptophytes. The prevailing group in relation to light are heliophytes $(53,69 \%)$, sciophytes are 5,36\%. Umbraticolous plants make $40,93 \%$ of flora. In relation to extent of moistening the prevailing group are mesophytes $(87,25 \%)$. The boreal component of the studied flora is presented by 105 species $(70,47 \%)$. The most part of polyzonal species are adventive. Of longitude groups most represented are Eurasian (19.46\%), Circumpolar (16.78\%), Far East (16.11\%) and Eurasian-American (14.09\%). Adventive species are represented mainly Eurasian elements. Set of the leading families, prevalence of mesophytic ecotypes and boreal habitat type show boreal character of flora, which corresponds to the zonal position of the city. The state of the natural complex of the park requires monitoring because of active recreational use of the territory.

Keywords: natural flora; natural monument; vascular plants; boreal flora; forest park.

УДК 581.52.582. 32.

МЕСТА ОБИТАНИЯ БРИОФИТОВ БАССЕЙНА АГАЛЫКСАЯ (КАРАТЕПИНСКИХ ГОР, ЗЕРАВШАНСКОГО ХРЕБТА)

(C) 2015

$\mathbf{X . X . Ж а л о в , ~ а с с и с т е н т ~ к а ф е д р ы ~ б о т а н и к и ~ и ~ ф и з и о л о г и и ~ р а с т е н и и ̆ ~}$ Самаркандский государственныии университет, Самарканд (Узбекистан)

Аннотация. Зеравшанский хребет остается одним из малоизученных в бриологическом отношении регионов. Для этой территории задача выявления видового состава листостебельных мхов и их эколого-биологических особенностей ранее не ставилась. На территории бассейна Агалыксая Каратепинских гор можно выделить четыре типа субстрата, на которых поселяются моховидные: почва, кора живых деревьев, гнилая древесина, камни. Характеристика субстратных групп осложняется достаточно широкой экологической валентностью мохообразных. Многие виды выбирают для своего поселения не один субстрат, а несколько.

За период исследований на почвах бассейна Агалыксая зарегистрировано 20 видов мохообразных из 13 родов и 10 семейств. На гнилой древесине зарегистрировано 9 видов мохообразных из 7 родов и 5 семейств. На коре живых деревьев зарегистрировано 15 видов мохообразных из 8 родов и 6 семейств. Эпилитные бриофиты поселяются на каменистых субстратах. На каменистых субстратах бассейне Агалыксая зарегистрировано 34 вида мохообразных из 16 родов и 13 семейств. На основании результатов, полученных при изучении субстратных групп моховидных бассейна Агаликсая, нами был проведен сравнительный анализ рассмотренных субстратных групп с целью выявления их характерных особенностей.

Ключевые слова: бриофлора; субстратные группы; экологическая валентность; гидрофит; гигрофит; мезофит; ксерофит. 